\title{
Assessment of microbial contamination of drinking water with total coliform bacteria and Escherichia coli in the Bitola region
}

\author{
Marta Nedelkova $^{1 *}$, Angela Delova ${ }^{1}$, Tanja Petreska Ivanovska ${ }^{2}, Z_{\text {Zoran } Z^{2} i v i k j}{ }^{2}$, \\ Lidija Petrushevska-Tozi ${ }^{2}$ \\ ${ }^{1}$ Centre of Public Health, Partizanska no number, 7000 Bitola, North Macedonia \\ ${ }^{2}$ Institute of Applied Biochemistry, Faculty of Pharmacy, Ss. Cyril and Methodius University, \\ Mother Theresa 47, 1000 Skopje, North Macedonia
}

Received: August 2019; Accepted: September 2019

\begin{abstract}
The aim of this paper is to analyze the presence of Escherichia coli (E. coli) and total coliform bacteria (CB) in the drinking water of urban and rural areas of the Bitola region, as indicators for water quality and safety. All water in urban area is chlorinated, while at the same time the water in rural areas is non-chlorinated. The samples were analyzed according to the international standard method of membrane filtration MKC EN ISO 9308-1:2015. In all examined samples of drinking water in urban area, presence of E. coli and CB was not detected as a result of the disinfection of the water. On contrary, in all tested samples of the water from the rural water supply, presence of E. coli and CB was confirmed. Significant increase in coliform bacterial counts probably weather-related was found in the period from April to September. In addition, in the third quarter including July, August, and September, in many measurements, E. coli as an indicator of faecal contamination was identified in drinking water. In accordance with these findings and in order to provide safe drinking water, it is necessary to modernize the water supply for the population in rural areas, to disinfect permanently the drinking water and to apply regular laboratory controls which are a basic pre-condition. Otherwise, inappropriate management of the water systems can cause serious decrease in the quality and safety of the drinking water associated with an increased risk of appearance of the infectious diseases in people and hydric epidemic.
\end{abstract}

Keywords: drinking water, Escherichia coli, coliform bacteria, membrane filtration

\section{Introduction}

The water is of vital importance to the living organisms. Providing access to safe water is one of the most efficient instruments for promotion of people's health. Safe and easily accessible water is important for the public health, no matter if it is used for drinking, for home use, for production of food or for recreational purposes. Good water supply, as well as effective management of water resources could strengthen the economic growth of the countries. In 2010, the general committee of United Nations (UN) admits the human right to water and sanitation. Everyone has the right to sufficient, continuous, safe, acceptable, physically accessible water for personal and home use (WHO, 2008).

The greatest risk for the microbiological contamination of the drinking water is the presence of human and animal faeces. The water provides vital

\footnotetext{
* marta.nedelkova@gmail.com
} 
elements, but when is contaminated it becomes a source of contagious diseases for the people (Karavoltsos et al., 2008). Microbe contamination of the drinking water causes acute and chronic damage to human health. Drinking of contaminated water with bacteria, viruses and protozoa, may induce a lot of infective diseases like cholera, typhoid, hepatitis and infective gastrointestinal diseases such as cryptosporidiosis and giardiasis. Usual symptoms of these diseases include fever, fatigue and weight loss, vomiting, abdominal cramps, diarrhea and stomach ache. In the worst cases it can lead to death. Some individuals are more sensitive to infections and suffer more serious from the above mentioned symptoms. These sensitive groups include babies, small children, pregnant women, older people and immune-compromised people (Onyango et al., 2018; Sacchetti et al., 2014).

The European Union (EU) regulations concerning the quality of the drinking water (European Council, 1998), set limitations for the presence of the microorganisms, creating necessity for careful monitoring of the quality of the drinking water (Bolelli et al., 2016). The term 'coliform bacteria' refers to gram-negative, rodshaped bacteria. They grow and are able to ferment the lactose at a temperature of $35-37{ }^{\circ} \mathrm{C}$ and produce acid, gas and aldehyde in the period of 24-28 h. They are also oxidase-negative and non-sporogenous bacteria and show activity when exposed to beta galactosidase (Rompré et al., 2002). The coliform bacteria generally belong to the following genera: Escherichia, Citrobacter, Enterobacter and Klebsiella. As it is defined with modern methods, coliforms are heterogeneous, including the bacteria that ferment the lactose such as Enterobacter cloacae and Citrobacter freundii. These species belong to the CB group as well and can otherwise be found in the faeces and in the natural habitat and in the water rich in nutritive substances, soil, decomposing organic substances (Rajendra et al., 2012). Consequently, total coliform counts give a general indication of the sanitary condition of a water supply. Faecal coliforms are the group of the total coliforms that are considered to be present specifically in the gut and feces of warm-blooded animals with Escherichia coli as the main representative which is generally not found growing and reproducing in the environment. It was isolated from faeces of a new born in 1885 by the German pediatrics and professor at the University of Gratz and Vienna, Escherich, and called it Bacterium coli. In 1920 this bacterium was classified in the genus Escherichia and was named as Escherichia coli. It is a gram negative, non-capsuled bacillus, aerobic and/or additionally anaerobic. The optimal temperature for its growth is $37^{\circ} \mathrm{C}$, with a range of $10-45^{\circ} \mathrm{C}$ (Chan et al., 2007). E. coli is considered to be the species of coliform bacteria that is the best indicator of faecal pollution and the possible presence of pathogens. In a few studies $E$. coli was reported to be the best indicator of faeces contamination of the drinking water (Farah et al., 2002; Pitkänen et al., 2007; Steyn et al., 2004).
Considering the risks related to presence of $\mathrm{CB}$ in drinking water, it is of utmost importance to find and apply the appropriate standard method for detection and enumeration of $E$. coli and $\mathrm{CB}$ in the drinking water. There are both classical and innovative methods for detection of coliform bacteria and E. coli: technique of multiple test tubes fermentation (MPN), membrane filtration technique (MT), enzyme methods and molecular methods (Pal, 2014). The method of membrane filtration (MF) was proposed and developed by Goetz and Tsuneishi (1951) which enabled a considerable saving of time, effort and costs for isolation, enumeration and identifying of indicative bacteria for evaluation of the water quality (Clark et al., 1951). MF continues to be useful for such analysis of different water samples, drinking water, and natural and sewage waters and is a standard practice in many laboratories for public health in USA and in Europe (APHA, 2005; International Organization for Standardization, 2014).

Most of the international directions and standards for quality testing procedures of the drinking water include examination of bacteria indicators as a measure for microbiological quality of the water according to the suggestions given in the rulebooks of regulations. Consequently, regulatory authorities around the world frequently review drinking water regulations, and the methodologies used to comply with these regulations. Within the European Union, the Drinking Water Directive (98/83/EC) specifies the parameters which must be tested for, the frequency of sampling and recommends the laboratory methods to be used. Frequently, the specified methods are ISO standards and are listed as reference methods in the Directive (European Union 1998 Council Directive 98/83/EC).

In the laboratory for sanitary microbiology in the Centre for public health in Bitola, regular control of detection and enumeration of coliform bacteria and E. coli in chlorinated and non-chlorinated drinking water is carried out according the Rulebook on requirements for safety and quality of the drinking water (Rulebook on Requirements for Safety and Quality of Drinking Water in the Republic of the North Macedonia, Official Gazette of Republic of Macedonia № 183, 2018). According to this Rulebook of regulations, the presence of coliform bacteria and $E$. coli in the drinking water is not permitted.

The aim of this paper was determination of microbiological quality of drinking water samples originating from urban and rural areas in the district of Bitola in 2018. All drinking water in urban area is chlorinated, while the water in rural areas is nonchlorinated, hence in the text that follows chlorinated refers to urban, while non-chlorinated refers to water from rural areas. For detection and enumeration of coliform bacteria and $E$. coli, the technique of MF was used and the applied method was in accordance with the international standard MKC EN ISO 9308-1:2015 (International Organization for Standardization, 2014). 
Table 1. Measurement points and number of drinking water samples in urban area

\begin{tabular}{cc}
\hline \hline Measurement points & Number of samples \\
\hline Elementary school & 48 \\
Highschool & 48 \\
Clinical Hospital & 48 \\
Home for high school students & 48 \\
Home for students & 48 \\
Kindergartens (4 different facilities) & 192 \\
Home for babies & 48 \\
Nursing home & 48 \\
Water supply for the urban Bitola - BAIR & 48 \\
\hline
\end{tabular}

\section{Materials and methods}

\section{Sampling}

The samples of chlorinated water were taken four times in every month (once a week) in 2018. The 12 measurement points covered the urban area, while the total number of analyzed chlorinated water samples was 576 (Table 1).

Non-chlorinated water samples were taken mainly from primary schools or private houses serving as measurement points of the rural area. The samples were taken at least 2 times in each quarter (four quarters, first from January to March, second from April to June, third from July to September and the fourth from October to December). Total number of non-chlorinated water samples was 273, taken from 33 measurement points. These measurement points were selected based on the level of contamination and sources of pollution (Table 2).

The water samples were taken in plastic sterile bottles (ISOLAB $^{\circledR}, \mathrm{GmbH}$ Laboratories, Germany) with volume of $500 \mathrm{~mL}$, stored at temperature of $4{ }^{\circ} \mathrm{C}$ and transported to the laboratory. For the chlorinated water samples, bottles with sodium thiosulfate $\left(\mathrm{Na}_{2} \mathrm{~S}_{2} \mathrm{O}_{3}\right)$ were used, and residual chlorine was measured on the spot by a trained professional. All the samples were bacteriologically analyzed within 6 hours of the sampling according to the standard MKC EN ISO 19458:2009 (International Organization for Standardization, 2009).

\section{Methodology}

The samples were analyzed according to ISO 93081:2015. The standard test is based on membrane filtration, incubation and differentiation of the agar medium and calculation of the number of the target organisms in the specimen.

A certain amount of water $(100 \mathrm{~mL})$ was filtered through net filters of the S-PAK type (Millipore S.A.S 6120 Molsheim, France), with a diameter of $47 \mathrm{~mm}$, and $0,45 \mu \mathrm{m}$ size of the filter pores. The filters were placed at an appropriate Chromogenic coliform agar medium (Biolife Italiana S.R.L, Milano, Italy) ensuring that no air is trapped underneath. The Petri dishes were incubated at Макед. фарм. билт., 65 (2) 23 - 32 (2019) the temperature of $36 \pm 2{ }^{\circ} \mathrm{C}$ for a time period of $21 \pm 3 \mathrm{~h}$. Then, the membrane filters were examined and the colonies were counted.

\section{Differentiation}

The grown colonies on the membrane filters were examined and counted.

- All the pink to red colonies (positive $\beta-\mathrm{D}$ galactosidase reaction) are regarded to be presumptive coliform bacteria.

- All the dark blue to violet colonies (positive $\beta-\mathrm{D}$ galactosidase and $\beta$-D-glucuronidase reaction) are E. coli.

To confirm the presumptive coliform bacteria, an oxidase test has to be performed. To this aim, at least 10 pink to red colonies were chosen. Oxidase test is most helpful in screening colonies suspected of being one of the coliform bacteria (all negative) and in identifying colonies suspected of belonging to other genera such as Aeromonas, Pseudomonas, Neisseria, Campylobacter, and Pasteurella (positive). These bacteria do not belong to the group of coliform bacteria, but are present in the intestinal flora of humans and animals and hence they can reach the drinking water. For this confirmation step, an appropriate commercialized oxidase test (Microbiology Anaero test ${ }^{\circledR}$, Sigma-Aldrich, Germany) was used. An appearance of a dark-blue colour within 30 s represents a positive oxidase reaction. This shall not be observed for coliform bacteria since they are oxidase negative.

\section{Calculation}

The number of E. coli and CB in $100 \mathrm{~mL}$ (CFU/100 $\mathrm{mL}$ ) was calculated according to the standard ISO 8199:2005 (International Organization for Standardization, 2005). The number of coliform bacteria is a total of all the oxidase negative pink to red colonies and dark blue to violet colonies. All dark blue to violet colonies are regarded to be E. coli. To calculate the number, the following formula was used Equation 1:

$$
C_{s}=\frac{z}{V_{\text {tot }}} x V_{s}
$$


where

- $\mathbf{C}_{\mathrm{s}}$ is the estimate of the number of CFU in the reference volume $\mathrm{V}_{\mathrm{s}}$ of the sample;

- $\mathbf{Z}$ is the sum of colonies counted on plates or on membranes derived from dilutions $d_{1}, d_{2}, \ldots, d_{i}$, or derived from separate volumes of the test portion (sample or dilution);

- $\mathbf{V}_{\mathbf{s}}$ is the reference volume chosen to express the concentration of the micro-organisms in the sample;

- $\mathbf{V}_{\text {tot }}$ is the calculated total volume of original sample included in the plates enumerated. Vtot is either the sum of the separate volumes from the test portion (sample or dilution) or calculated using the Equation 2:

$\mathrm{V}_{\text {tot }}=\left(\mathrm{n}_{1} \mathrm{~V}_{1} \mathrm{~d}_{1}\right)+\left(\mathrm{n}_{2} \mathrm{~V}_{2} \mathrm{~d}_{2}\right)+\ldots \ldots+\left(\mathrm{n}_{\mathrm{i}} \mathrm{V}_{\mathrm{i}} \mathrm{d}_{\mathrm{i}}\right)$

where

- $\mathbf{n}_{1}, \mathbf{n}_{2}, \ldots, \mathbf{n}_{\mathbf{i}}$ is the number of plates counted for dilution $\mathrm{d}_{1}, \mathrm{~d}_{2}, \ldots, \mathrm{d}_{\mathrm{i}}$;

$-V_{1}, V_{2}, \ldots, V_{i}$ is the test volume used with the dilution $\mathrm{d}_{1}, \mathrm{~d}_{2}, \ldots, \mathrm{d}_{\mathrm{i}}$;

$-\mathbf{d}_{1}, \mathbf{d}_{2}, \ldots, \mathbf{d}_{\mathbf{i}}$ is the dilution used for the test portion volume $\mathrm{V}_{1}, \mathrm{~V}_{2}, \ldots, \mathrm{V}_{\mathrm{i}}(\mathrm{d}=1$ for an undiluted sample, $\mathrm{d}=0,1$ for a ten-fold dilution, etc.).

Since each colony is assumed to have arisen from one micro-organism or from a single aggregate of microorganisms, the result is expressed as the number of colony-forming units (CFU) in a specified reference volume of the sample of $100 \mathrm{~mL}$.

\section{Results and discussion}

In this paper, 849 water samples were analyzed, of which 576 samples were chlorinated water (all from urban area), while the rest 273 samples of the total number were non-chlorinated water (all from rural area). The results have shown absence of $E$. coli and $\mathrm{CB}$ in all assayed samples of chlorinated water as a result of the chlorination of the water i.e. its disinfection. With the disinfection of the water, successful elimination of the pathogenic bacteria which are associated with serious risk to trigger infective diseases within the population has been provided. Chlorine or hypochlorite added to drinking water is highly toxic to microorganisms, and prevents the spread of waterborne diseases (Martino, 2019). The transfer of the diseases such as typhoid and paratyphoid fevers, cholera, salmonellosis and shigellosis can be controlled by treatments which significantly reduce the total number of sustainable microorganisms in the water (Milojevic, 2004). Since the prevention of people's health from consequences related to faecal water contamination is an essence (Bumadian et al., 2013), the chlorination of the water can be seen as an effective way to provide safe and clean water for the consumers. The chlorination of drinking water is a public health measure that was introduced to control microbial contamination in the early $20^{\text {th }}$ century, and still remains the most common drinking water disinfectant used around the world today (National Health and Medical Research Council, 2012).

The obtained results for presence of $\mathrm{CB}$ and $\mathrm{E}$. coli $(\mathrm{CFU} / 100 \mathrm{~mL})$ in non-chlorinated drinking waters and respective bacterial counts are presented quarterly, derived from analysis of each measuring point.

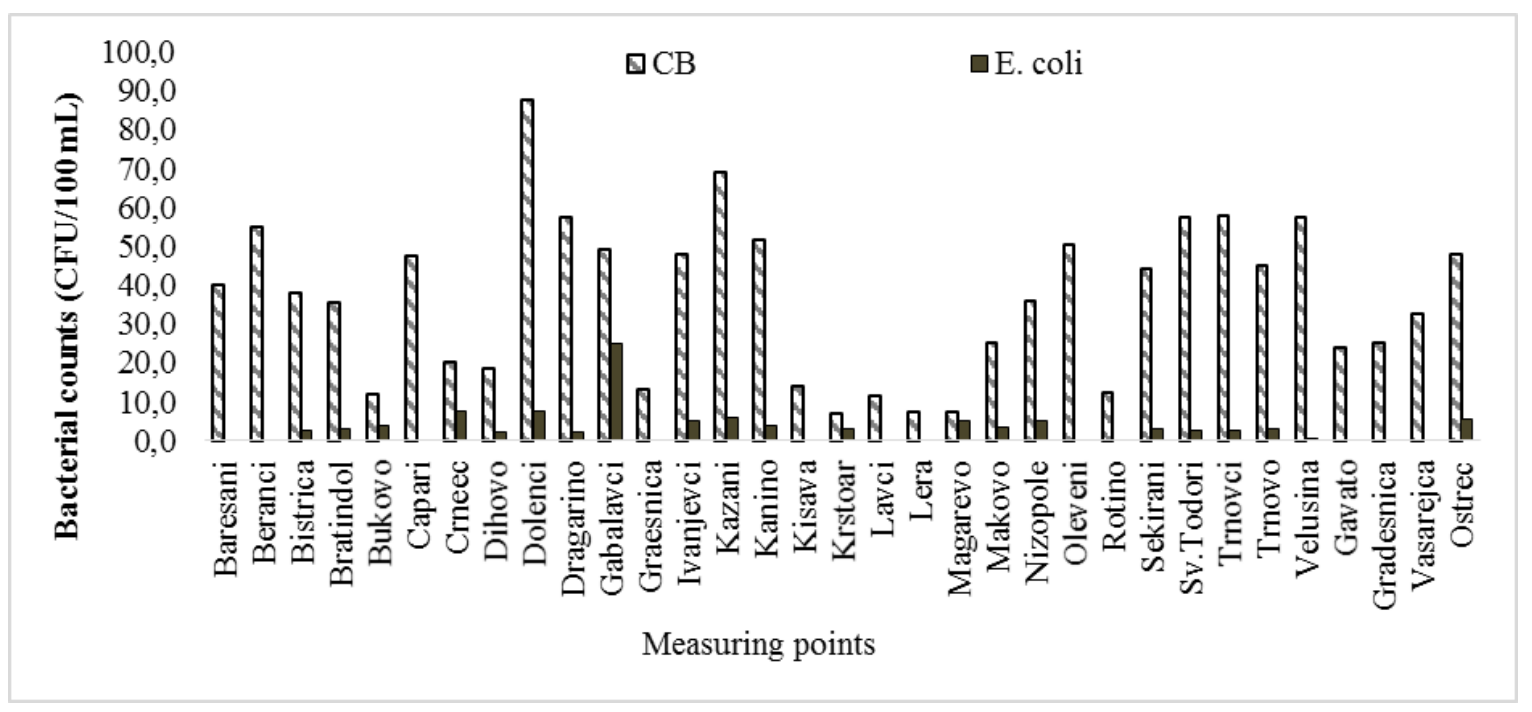

Fig. 1. Presence of total coliform bacteria and faecal coliforms (Escherichia coli) isolated from the rural (nonchlorinated) drinking water in quarter I (January, February, and March during 2018) and their respective counts $(\mathrm{CFU} / \mathrm{mL})$. 
Table 2. Measurement points and number of drinking water samples in rural area

\begin{tabular}{|c|c|c|c|c|}
\hline \multirow[t]{2}{*}{ Measurement points } & \multicolumn{4}{|c|}{ Number of samples } \\
\hline & I quarter & II quarter & III quarter & IV quarter \\
\hline Elementary school, Baresani & 2 & 2 & 2 & 2 \\
\hline Elementary school, Beranci & 2 & 2 & 2 & 2 \\
\hline Elementary school, Bistrica & 2 & 2 & 2 & 3 \\
\hline Elementary school, Bratindol & 3 & 2 & 2 & 2 \\
\hline Elementary school, Bukovo & 3 & 2 & 2 & 2 \\
\hline Elementary school, Capari & 2 & 2 & 2 & 2 \\
\hline Private house, Crneec & 2 & 2 & 2 & 2 \\
\hline Elementary school, Dihovo & 2 & 2 & 2 & 2 \\
\hline Elementary school,Dolenci & 2 & 2 & 2 & 2 \\
\hline Private house, Dragarino & 2 & 2 & 2 & 2 \\
\hline Elementary school,Gabalavci & 3 & 2 & 2 & 2 \\
\hline Elementary school, Graesnica & 2 & 2 & 2 & 2 \\
\hline Elementary school, Ivanjevci & 2 & 2 & 2 & 2 \\
\hline Private house, Kazani & 2 & 2 & 2 & 2 \\
\hline Elementary school, Kanino & 2 & 2 & 2 & 2 \\
\hline Elementary school, Kisava & 2 & 2 & 2 & 2 \\
\hline Private house, Krstoar & 2 & 2 & 2 & 2 \\
\hline Private house, Lavci & 2 & 2 & 2 & 2 \\
\hline 2P2r2ivate house, Lera & 2 & 2 & 2 & 2 \\
\hline Private house, Magarevo & 3 & 2 & 2 & 2 \\
\hline Private house, Makovo & 2 & 2 & 2 & 2 \\
\hline Private house, Nizopole & 3 & 2 & 2 & 2 \\
\hline Elementary school, Oleveni & 2 & 2 & 2 & 2 \\
\hline Private house, Rotino & 2 & 2 & 2 & 2 \\
\hline Private house, Sekirani & 2 & 2 & 2 & 2 \\
\hline Elementary school, Sv.Todori & 2 & 2 & 2 & 2 \\
\hline Elementary school, Trnovci & 2 & 2 & 2 & 2 \\
\hline Private house, Trnovo & 2 & 3 & 3 & 2 \\
\hline Private house, Velusina & 2 & 2 & 2 & 2 \\
\hline Private house, Gavato & 2 & 2 & 2 & 2 \\
\hline Private house, Gradesnica & 2 & 2 & 2 & 3 \\
\hline Elementary school, Vasarejca & 2 & 2 & 2 & 2 \\
\hline Private house, Ostrec & 2 & 2 & 2 & 2 \\
\hline
\end{tabular}

Based on the analysis of water samples from the local water supply network in the first quarter (January, February, and March) of 2018 in Bitola region (Figure 1), presence of $\mathrm{CB}$ was noticed at all measuring points, while the faecal coliform bacterium E. coli was detected in 20 of the tested 33 samples. During the winter period, increased moisture due to natural occurrences of rain and snow, allowed rainfalls to penetrate into underground water sources contributing $\mathrm{CB}$ and $\mathrm{E}$. coli to reach the drinking water. Given that the drinking water must not contain any colony of $\mathrm{CB}$ and $\mathrm{E}$. coli in an aliquot of $100 \mathrm{~mL}$ (Rulebook on Requirements for Safety and Quality of Drinking Water in the Republic of the North Macedonia, Official Gazette of Republic of Macedonia № 183, 2018), the results obtained for the quarter I showed that the tested samples of non-chlorinated water were a health- related irregular drinking water.

In the examinations conducted in quarter II (April, May, and June) of the year 2018, coliform bacteria and E. coli were also found in drinking water samples taken from local water supply network (Figure 2). CB were determined in all tested samples counting in a range of 7 to $160 \mathrm{CFU} / 100 \mathrm{~mL}$, while E. coli was detected in 18 samples of local water supplies. Comparing the results shown for quarters I and II on annual level, it can be assumed that bacterial counts were generally increased in quarter II. Such contamination may be weather-related due to the exposure of surface water sources to the impact of natural occurrences such as increased air temperature and rainfalls as well. However, it cannot be excluded that the microbial faecal contamination was caused by anthropogenic sources such as wastewater discharge. 


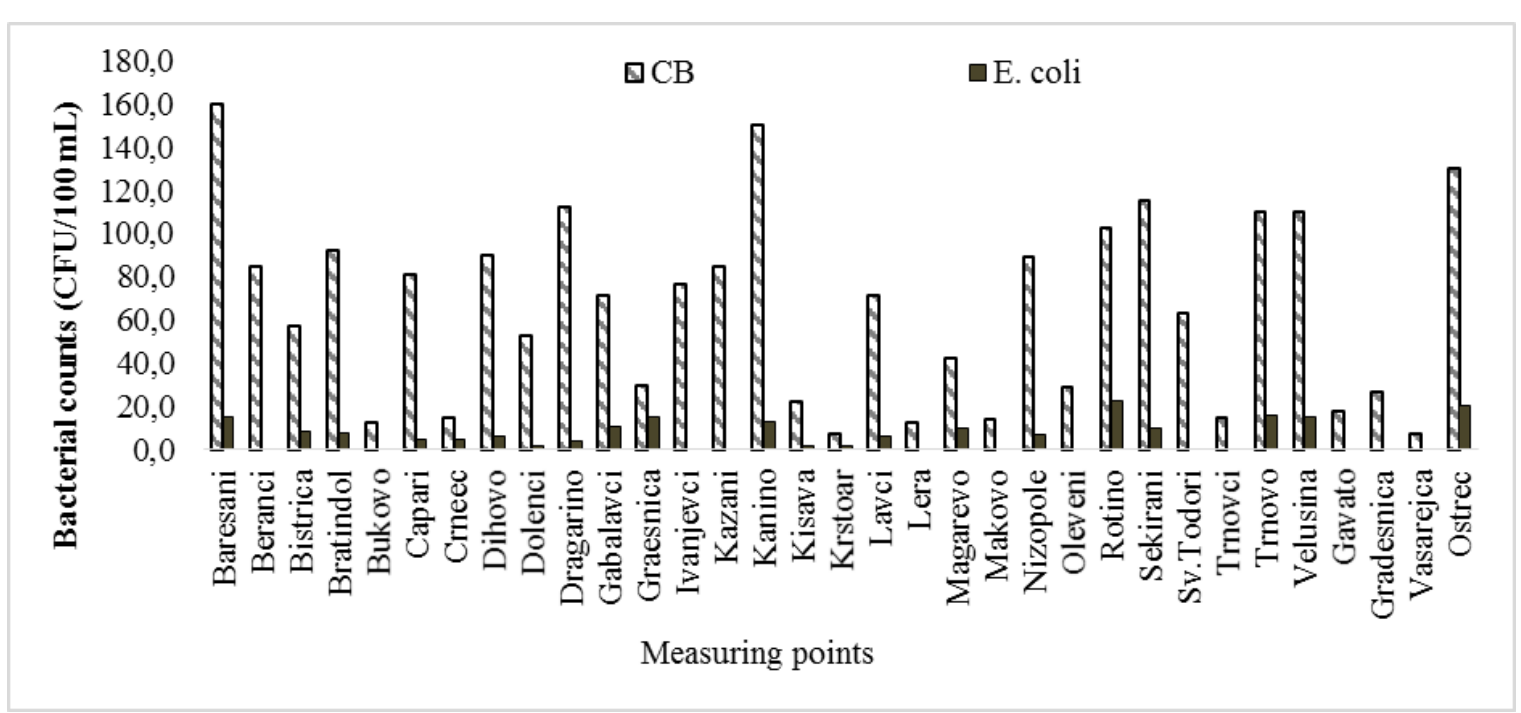

Fig. 2. Presence of total coliform bacteria and faecal coliforms (Escherichia coli) isolated from the rural (nonchlorinated) drinking water in quarter II (April, May, and June during 2018) and their respective counts $(\mathrm{CFU} / \mathrm{mL})$.

In the third quarter measurements (October, November, and December during 2018), highest count of total coliforms was enumerated (measuring point Gabalavci, $175 \mathrm{CFU} / 100 \mathrm{~mL}$ ). In respect to E. coli as an indicator of faecal contamination it was identified in the majority of non-chlorinated water samples respective to 23 different measuring points (Figure 3). Taking into account that this period reflects the summer months of the year, a sudden increase in the temperature of the air, water and soil forming an ideal environment for bacterial reproduction may explain the sustainable water contamination. In addition, at this time, livestock is fed at the pastures and their faeces can easily reach and contaminate the drinking waters. Thus, certain measuring points are characterized by the highest counts for $\mathrm{CB}$ and/or E. coli compared to the respective measuring points in other seasons of the year.

The results for non-chlorinated water contamination with $\mathrm{CB}$ and E. coli regarding the quarter IV (October, November, and December during 2018) are presented in Figure 4. CB counts ranged from 7.5 to $118 \mathrm{CFU} / 100 \mathrm{~mL}$, while E. coli was identified in drinking water taken from 17 measuring points. Identically as it was hypothesized for the first quarter, the main reason for the presence of $\mathrm{CB}$ and E. coli may be the increased amount of rain and snow as well. Further, because of the undefined protective zones around the springs and wells, the precipitation water as well as the decomposition of organic material, cause microbial contamination of the spring water allowing persistence of $\mathrm{CB}$ and E. coli.

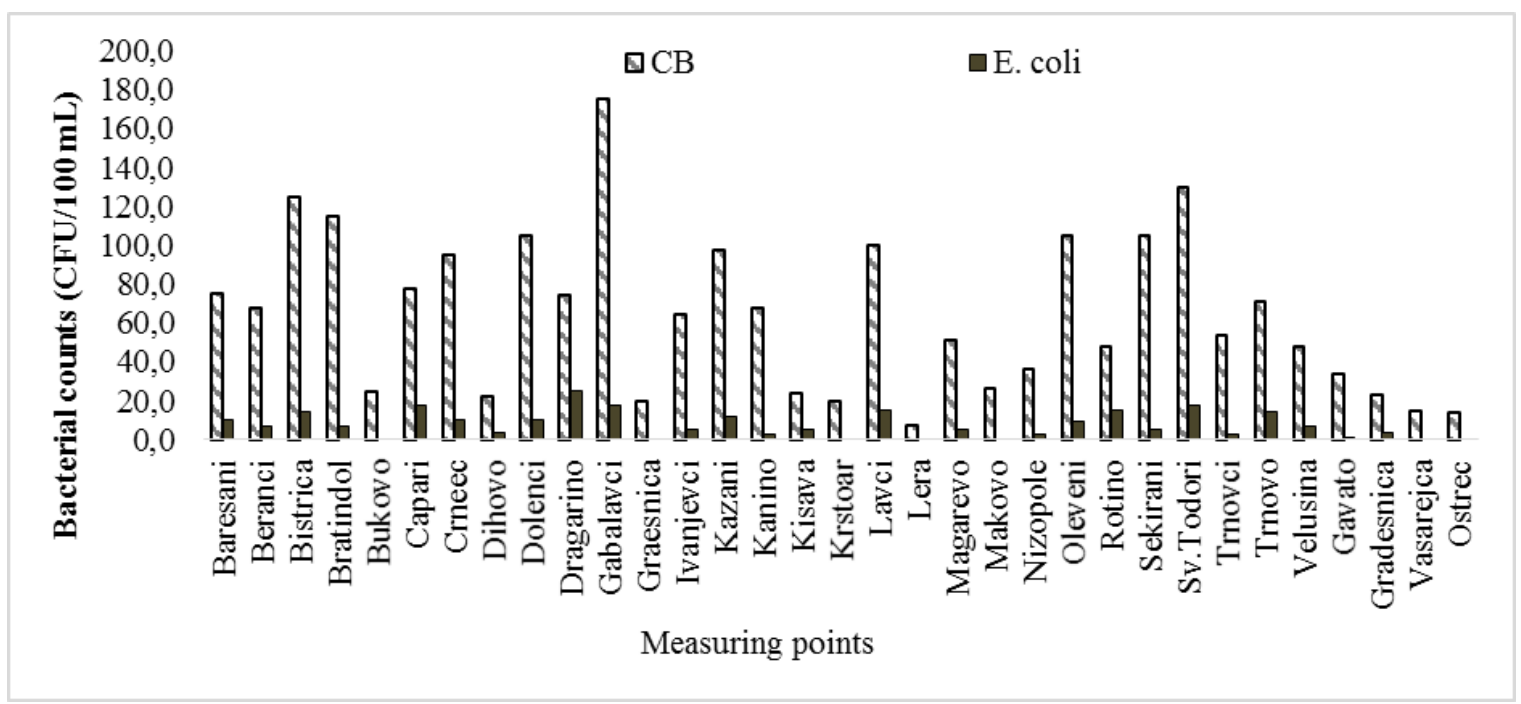

Fig. 3. Presence of total coliform bacteria and faecal coliforms (Escherichia coli) isolated from the rural (nonchlorinated) drinking water in quarter III (July, August, and September during 2018) and their respective counts $(\mathrm{CFU} / \mathrm{mL})$. 


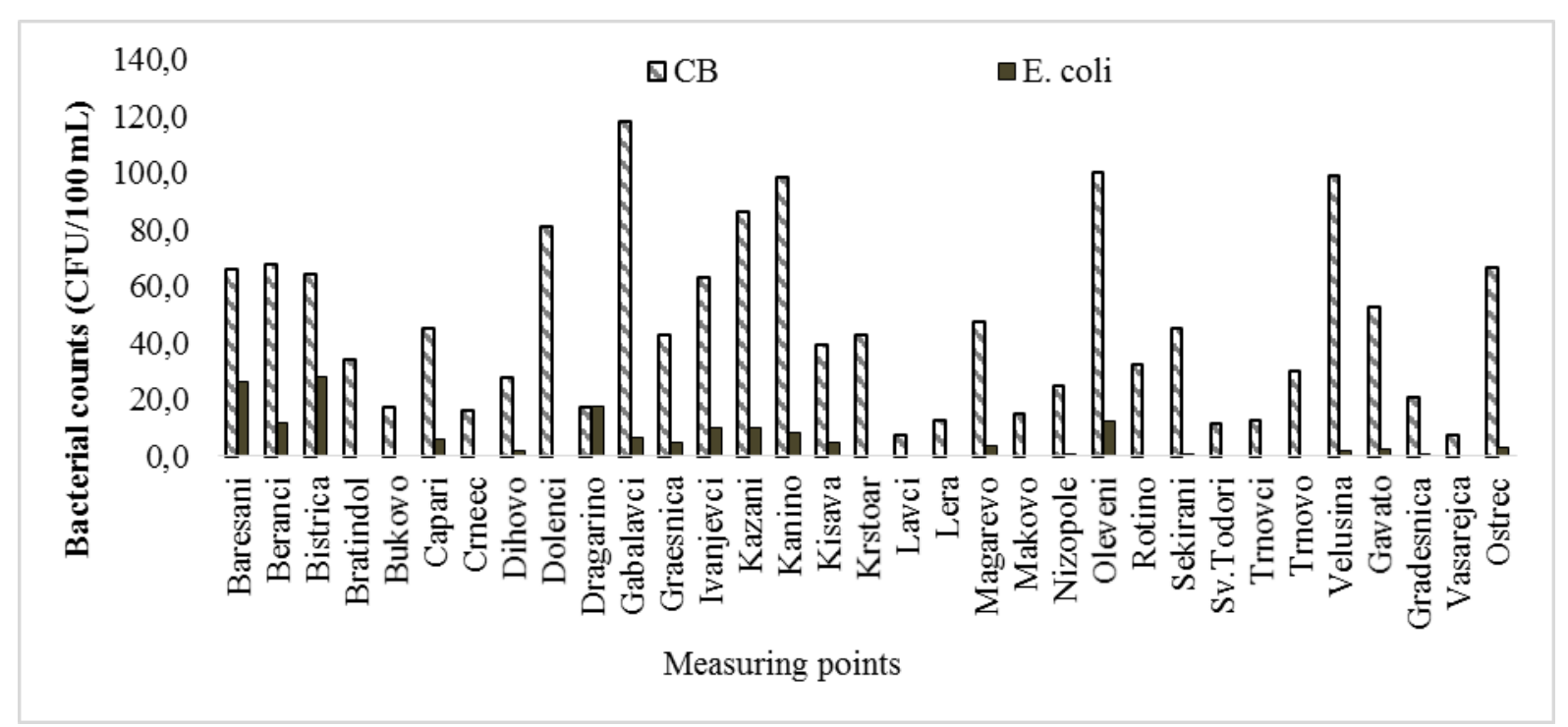

Fig. 4. Presence of total coliform bacteria and faecal coliforms (Escherichia coli) isolated from the rural (nonchlorinated) drinking water in quarter IV (October, November, and December during 2018) and their respective counts $(\mathrm{CFU} / \mathrm{mL})$.

E. coli and $\mathrm{CB}$ are recommended by many authors (Edberg et al., 2000; Garcia-Armisen et al., 2007; Hamilton et al., 2005; Leclerc et al., 2001) and publications (APHA, 2007; United States Environmental Protection Agency, 2004; WHO, 2008) to be studied as indicators for water contamination with the aim to protect the public health. Alone here, the adoption of standards will represent a major improvement for the microbiological monitoring of water quality intended to be used as drinking water source, irrigation of crops and aquaculture.

The poor quality in microbiological sense, i.e. contamination of non-chlorinated drinking water is a result of the exposure of the springs and wells to the impact of the natural conditions such as change in temperature of the air, water, soil and rain; physical and biochemical changes in the water content as well as pollution from the living world in nature (Milojevic, 2004). Furthermore, protective zones around the springs of drinking water, water collectors, reservoirs and watersupply systems are undefined, old and not well kept. The systems lack appropriate equipment for re-cleaning and disinfection, and if they have, it is not done continuously and it is not in a compliance with the regulations for drinking water disinfection. Hence, controlling of microbial contamination is a major aspect of water quality management. Chlorine or hypochlorite added to metropolitan drinking water is highly toxic to microorganisms, and prevents the spread of waterborne diseases. One of the earliest known uses of chlorine to disinfect public water supplies dates back to 1854 when celebrated epidemiologist Dr John Snow attempted to disinfect the Broad Street Pump water supply in London following an outbreak of cholera (Christman, 1998). It virtually eliminated waterborne diseases (Karumathil et al., 2014), which prior to this accounted for as many deaths as modern-day road accidents. Although several alternative methods for disinfecting public drinking water exist, chlorine has a major advantage in that it produces a residual disinfectant that is moderately persistent (National Health and Medical Research Council, 2012). It is also cheap, easy to manage, and scalable to large distribution networks. It is common practice to attempt to maintain adequate chlorine residual throughout the distribution system. The chlorine-based disinfection of raw water is essential to sustainable development, where contaminated water remains the greatest threat to public health in developing countries. In 1990, diarrheal disease caused by waterborne pathogens killed more than three million young children under the age of five (Christman, 1998). Estimates suggest that the disinfection of public drinking water has contributed to a $50 \%$ increase in life expectancy in developed countries in the $20^{\text {th }}$ century (Christman, 1998), chiefly through the control of waterborne diseases such as cholera, typhoid, dysentery, and hepatitis A. Clearly, water chlorination protects against a substantial burden of childhood mortality, and this message must be balanced against any assertions related to a theoretical increase in childhood morbidity.

Comprising all above discussed and at the same time to solve the problem with microbial contamination of the local water sources in rural area of Bitola region, it is necessary to modernize the water-supplying system. In fact, permanent disinfection of the drinking water has to be provided and the rural communities with local watersupplies should join the urban water-supplies in Bitola. This will allow regular laboratory controls to be applied on routine basis, which are the key pre-conditions for proper water quality management and ensuring hygienically clean and safe water for each consumer.

Макед. фарм. билт., 65 (2) 23 - 32 (2019) 


\section{Conclusion}

In this paper, the absence and/or presence of Escherichia coli (E. coli) and total coliform bacteria (CB) in the chlorinated water in the urban and non-chlorinated water in the rural areas of the Bitola region, was analyzed. In all the examined samples of chlorinated water, presence of $\mathrm{CB}$ and $E$. coli was not detected which confirmed the safety of chlorinated drinking water. However, in all the examined samples of non-chlorinated water $\mathrm{CB}$ were identified, while E. coli was observed in the majority of the tested samples. The non-chlorinated waters did not comply with our national requirements for safety and quality of drinking water (Rulebook on Requirements for Safety and Quality of Drinking Water in the Republic of the North Macedonia, Official Gazette of Republic of Macedonia № 183, 2018) possessing an epidemiological risk in a view of protection of the public health. In addition, of all the carried out sanitary-hygienic insights of the water collectors, reservoirs and the network of the rural water-supply, it was confirmed that the largest number of objects for water supplying did not meet the sanitary-hygienic requirements.

The data presented suggest that the local watersupplying sources in rural region of Bitola are inferior to the urban water-supplying system in microbiological quality and it is urgent appropriate and immediate measures to be applied to overcome serious risks associated with human health in these areas.

\section{References}

American Public Health Association (APHA), 2005. Standard methods for the examination of water and wastewater, 21st ed. APHA, Washington DC, USA.

American Public Health Association (APHA), 2007. Standard methods for the examination of water and wastewater, Standard methods online, Section 9060, Samples. APHA, Washington DC, USA.

Bolelli, L., Ferri, E.N., Girotti, S., 2016. Control of microbial contamination in drinking water from micro filtering dispensers by dialysis ultrafilters. Ovidius University Annals of Chemistry 27(2), 87-93. Available at: https://doi.org/10.1515/auoc-2016-0014.

Bumadian, M.M., Almansury, H.H., Bozakouk, I.H., Lawgali, Y.F., Bleiblo, F.A., 2013. Detection and enumeration of coliform bacteria in drinking water at hospital of Benghazi/Libya. J. Exp. Biol. 1(6), 436-440.

Chan, C.L., Zalifah, M.K., Norrakiah, A.S., 2007. Microbiological and physicochemical quality of drinking water. Malaysian Journal of Analytical Sciences 11(2), 414-420.

Christman, K., 1998. The History of Chlorine. Chlorine Chemistry Council, Arlington, VA, USA.

Clark, H.F., Geldreich, E.E., Jeter, H.L., Kabler, P.W., 1951. The membrane filter in sanitary bacteriology. Public health reports (Washington, DC: 1896) 66(30), 951-977.

Edberg, S.C.L., Rice, E.W., Karlin, R.J., Allen, M.J., 2000. Escherichia coli: the best biological drinking water indicator for public health protection. J. Appl. Microbiol. 88(S1), 106S-116S.

European Council, 1998. Directive 98/83/EC On the quality of water intended for human consumption. Official Journal of the European Communities 330, 32-54. Available at: https://eur-lex.europa.eu/LexUriServ/LexUriServ.do?uri= OJ:L:1998:330:0032:0054:EN:PDF.

Farah, N., Zia, M.A., Rehman, K., Sheikh, M., 2002. Quality characteristics and treatment of drinking water of Faisalabad city. Int. J. Agric. Biol. 3, 347-349. Available at:http://www.fspublishers.org/published_papers/95873_.p df

Garcia-Armisen, T., Prats, J., Servais, P., 2007. Comparison of culturable fecal coliforms and Escherichia coli enumeration in freshwaters. Can. J. Microbiol. 53(6), 798801. Availavle at: https://doi.org/10.1139/W07-033.

Hamilton, W.P., Kim, M., Thackston, E.L., 2005. Comparison of commercially available Escherichia coli enumeration tests: Implications for attaining water quality standards. Water Res. 39(20), 4869-4878. Available at: https://doi.org/10.1016/j.watres.2005.02.006.

International Organization for Standardization, 2005. MKC EN ISO 8199:2005 Water quality -General guidance on the enumeration of micro-organisms by culture. Available at: https://www.iso.org/standard/37011.html. Last accessed: June, 2019.

International Organization for Standardization, 2014. MKC ISO 9308-1:2014 Water quality - Enumeration of Escherichia coli and coliform bacteria. Part 1: Method of membrane filtration for water with low bacteria background flora. Available at: https://www.iso.org/standard/55832.html. Last accessed: June, 2019.

International Organization for Standardization, 2009. MKC EN ISO 19458:2009 Water quality - Sampling for microbiological analysis. Available at: https://www.iso.org/standard/33845.html. Last accessed: June, 2019.

Karavoltsos, S., Sakellari, A., Mihopoulos, N., Dassenakis, M., Scoullos, M.J., 2008. Evaluation of the quality of drinking water in regions of Greece. Desalination 224(1-3), 317329. Available at: https://doi.org/10.1016/j.desal.2007.06.013.

Karumathil, D., Yin, H.B., Kollanoor-Johny, A., Venkitanarayanan, K., 2014. Effect of chlorine exposure on the survival and antibiotic gene expression of multidrug resistant Acinetobacter baumannii in water. Int. J. Environ. Res. Public Health 11(2), 1844-1854. Available at: https://doi.org/10.3390/ijerph110201844.

Leclerc, H.D.A.A., Mossel, D.A.A., Edberg, S.C., Struijk, C.B., 2001. Advances in the bacteriology of the coliform group: their suitability as markers of microbial water safety. Annu. Rev. Microbiol. 55(1), 201-234. Available at: https://doi.org/10.1146/annurev.micro.55.1.201.

Martino, D., 2019. The effects of chlorinated drinking water on the assembly of the intestinal microbiome. Challenges 10(10), 1-7. Available at: https://doi.org/10.3390/challe10010010.

Milojevic, M., 2004. Kvalitet vode u vodovodima. Vodoprivreda 36, 339-360.

National Health and Medical Research Council, 2012. Infant feeding guidelines information for health workers, 56th ed. National Health and Medical Research Council, Canberra, Australia. 
Onyango, A.E., Okoth, M.W., Kunyanga, C.N., Aliwa, B.O. 2018. Microbiological quality and contamination level of water sources in Isiolo County in Kenya. J. Environ. Public Health, 2018, ID 2139867. Available at: https://doi.org/10.1155/2018/2139867

Pal, P., 2014. Detection of coliforms in drinking water and its effect on human health - A review. Int. Lett. Nat. Sci. 17, 122-131. Available at: https://doi.org/10.18052/www.scipress.com/ILNS.17.122.

Pitkänen, T., Paakkari, P., Miettinen, I.T., Heinonen-Tanski, H., Paulin, L., Hänninen, M.L., 2007. Comparison of media for enumeration of coliform bacteria and Escherichia coli in non-disinfected water. J. Microbiol. Methods 68(3), 522529. Available at: https://doi.org/10.1016/j.mimet.2006.10.007.

Rajendra, S., Rubin, D., Abhishek, M., 2012. Microbiological quality of potable water in Dehradun city. Int. Res. J. Pharm. 3(6), 130-137.

Rompré, A., Servais, P., Baudart, J., De-Roubin, M.R., Laurent, P., 2002. Detection and enumeration of coliforms in drinking water: current methods and emerging approaches. J. Microbiol. Methods 49(1), 31-54. Available at: https://doi.org/10.1016/S0167-7012(01)00351-7.
Rulebook on Requirements for safety and quality of drinking water in the Republic of the North Macedonia, Official Gazette of Republic of Macedonia № 183, 2018. Available at: http://www.slvesnik.com.mk/Issues/286e4acf37c84e09a 6f840347dc789a2.pdf. Last assessed: June, 2019

Sacchetti, R., De Luca, G., Dormi, A., Guberti, E., Zanetti, F., 2014. Microbial quality of drinking water from microfiltered water dispensers. Int. J. Hyg. Environ. Health 217(2-3), 255-259. Available at: https://doi.org/10.1016/j.ijheh.2013.06.002.

Steyn, M., Jagals, P., Genthe, B., 2004. Assessment of microbial infection risks posed by ingestion of water during domestic water use and full-contact recreation in a mid-southern African region. Water Sci. Technol. 50(1), 301-308. Available at: https://doi.org/ 10.2166/wst.2004.0071.

United States Environmental Protection Agency, 2004. Implementation guidance for ambient water quality for bacteria. EPA, Washington DC, USA. Available at: https://www.epa.gov. Last assessed: February 22, 2019.

World Health Organization (WHO), 2008. Guidelines for Drinking-water quality, incorporating 1st and 2nd Addenda, Volume 1, Recommendations, third ed. WHO, Geneva, Switzerland.

\title{
Проценка на микробиолошкото загадување на водата
} за пиење со вкупни колиформни бактерии и Escherichia coli во регионот на Битола

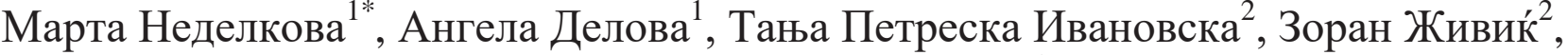 \\ Лидија Петрушевска-Този ${ }^{2}$
}

${ }^{1}$ Центар за јавно здравје, Партизанска бб, 7000 Битола, Република Северна Македонија

${ }^{2}$ Институт за применета биохемија, Фармачевтски факултет, Универзитет „Св. Кирил и Методиј”, Мајка Тереза 47, 1000 Скопје, Република Северна Македонија

Клучни зборови: вода за пиење, Escherichia coli, колиформни бактерии, мембранска филтрација

Во овој труд беше анализирано присуството на Escherichia coli (E. coli) и вкупните колиформни бактерии (CВ) како индикатори за квалитетот и безбедноста на водата за пиење со потекло од урбаната и руралната област на Битола. Примероците на вода земени од градското подрачје претставуваат хлорирана вода, додека пак испитуваните примероци на вода од приградскиот регион не се хлорирани. Анализата на сите примероци беше направена со примена на интернационалниот стандарден метод на мембранска филтрација MKC EN ISO 93081:2015. Како резултат на претходната дезинфекција на водата, во примероците од градската водоводна мрежа беше утврдено отсуство на СB и E. coli. За разлика од овие примероци, во водата со потекло од приградското подрачје беа детектирани E. coli и CB. Притоа, значаен пораст на бројот на колиформни бактерии беше забележан во периодот од април до септември што веројатно се должи на топлото време. Во летните месеци, јули, август и септември, во поголем број од анализите беше забележано присуство и на E. coli како сигурен индикатор на фекално загадување на водата за пиење. Во согласност со овие податоци, а со цел да се обезбеди хигиенски и 
здравствено исправна вода за пиење е неопходна модернизација на системот за снабдување со вода во руралната област на Битола На овој начин ќе се овозможи континуирана дезинфекција на водата за пиење и примена на стандардните лабораториски методи за контрола како основни предуслови во обезбедувањето на квалитетна вода за пиење. Во спротивно, постои можност за опасно загрозување на квалитетот и безбедноста на водата за пиење што е поврзано со зголемен ризик од инфективни заболувања и хидрични епидемии. 